\title{
Konsep Diri Polisi Wanita (Polwan) dalam Konteks Komunikasi Interpersonal di Polres Metro Bekasi
}

\section{Self-Concept of Female Police (Polwan) in Interpersonal Communication Context at Polres Metro Bekasi}

\author{
Kadek Alda Rahmawati ${ }^{1}$, Maylanny Christin ${ }^{2}$ \\ ${ }^{1,2}$ Universitas Telkom, Bandung \\ Jl. Telekomunikasi No. 1, Bandung, Jawa Barat, Indonesia \\ Email : kadekaldarahmawati@gmail.com ${ }^{1}$
}

Received : April 24, 2021 ; Revised: June 17, 2021; Accepted: August 2, 2021

\begin{abstract}
Working as policewomen is a challenging profession. As women, policewomen must be prepared to face a plethora of issues and conservative opposition from society, perform activities that are typically associated with men, have a feminine side in acting and protecting the community, and face domestic responsibilities. Policewomen are expected to have a strong self-concept in dealing with the risks of their job. This study aimed at understanding and determining the detailed description of policewomen self-concept in the context of interpersonal communication at the Bekasi Metro Police. This research employed a qualitative method with a phenomenological approach. The theory of selfconcept and interpersonal communication was applied in this study. The four key informants were chosen using a purposive sample technique based on several criteria, including having served for at least four years and each representing one rank to ensure that there were differences in service experience. Observation, in-depth interviews, and documentation were used to collect data. After going through the data collection, data reduction, data display, and conclusion drawing processes, details of the policewoman's positive self-concept were discovered, which were characterized by five characteristics: being confident in their abilities, feeling equal to others, receiving praise without shame, understanding that everyone has different opinions, and having the ability for selfimprovement. In interpersonal communication, a positive self-concept is required to strengthen the communication abilities of the informant both at work and in daily life, and it also plays critical role in enhancing informant's confidence to take the opportunity in honing their interpersonal skills. In addition, the researcher obtained fourteen symbolic meanings packaged from the experiences and pure thoughts of policewomen.
\end{abstract}

Keywords: policewomen; self-concept; symbolic meaning

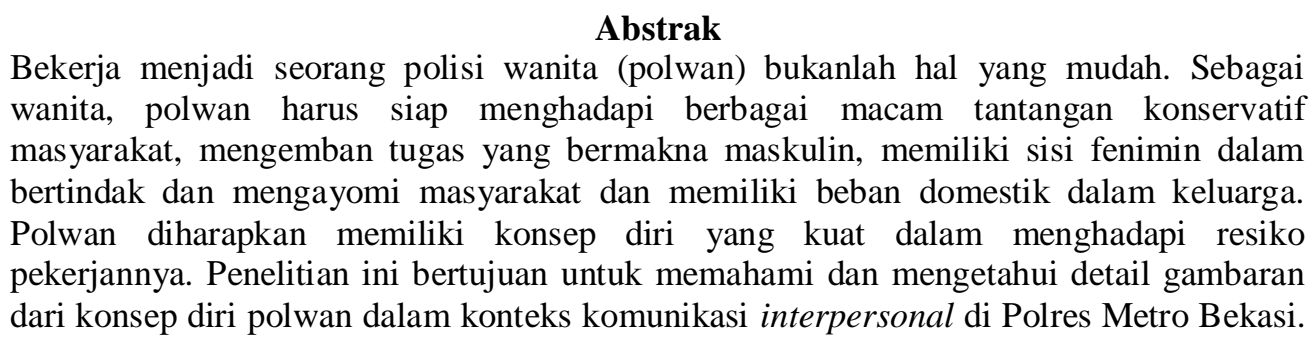


Penelitian ini merupakan penelitian kualitatif yang dianalisis dengan pendekatan fenomenologis. Teori yang digunakan dalam penelitian ini adalah teori konsep diri dan komunikasi interpersonal. Keempat informan kunci dipilih menggunakan teknik purposive sampling dengan beberapa kriteria diantaranya yaitu minimal telah berdinas selama 4 tahun dan setiap informan mewakili satu pangkat yang ada sehingga terdapat perbedaan pengalaman selama berdinas. Pengumpulan data dilakukan dengan teknik observasi, wawancara mendalam dan dokumentasi. Setelah melalui proses data collection, data reduction, data display dan conclusion drawing, ditemukanlah detail konsep diri positif polwan yang ditandai dengan lima hal, yaitu yakin dengan kemampuan dirinya, merasa setara dengan orang lain, menerima pujian tanpa rasa malu, memahami bahwa setiap orang memiliki pendapat yang berbeda dan memiliki kemampuan untuk memperbaiki diri. Pada komunikasi interpersonal, konsep diri positif dibutuhkan untuk mengasah kemampuan komunikasi informan baik saat berdinas maupun dalam kehidupan sehari-hari dan mengambil peran penting dalam kepercayaan diri informan untuk mengambil peluang pengalaman mengasah kemampuan interpersonalnya agar lebih baik. Peneliti juga mendapatkan empat belas makna simbolis yang dikemas melalui pengalaman dan hasil pemikiran murni polwan.

Kata Kunci: konsep diri; makna simbolis; polwan.

\section{Pendahuluan}

Bekerja bukan hanya kegiatan yang dilakukan untuk memenuhi kebutuhan sehari-hari, tetapi dalam arti yang lebih dalam lagi bekerja merupakan kegiatan yang dilakukan untuk menunjukan eksistensi manusia. Kegiatan bekerja saat ini memengaruhi harga diri seseorang karena dengan bekerjalah potensi atau kemampuan manusia tersebut dinilai.

Namun sayangnya lingkungan sosial telah membebankan wanita dengan stigma. Wanita pekerja dianggap gagal dalam menjalankan tugas utamanya, yaitu dalam berumah tangga. Pandangan tersebut melekat sedemikian rupa dalam sisi psikologis wanita hingga berubah menjadi sebuah sistem sosial yang mengekang ambisi wanita dalam bekerja. Istilah emansipasi kemudian muncul sebagai bentuk tindak lanjut dari gagasan kesetaraan gender.
R.A. Kartini merupakan salah satu pelopor emansipasi di Indonesia karena usahanya yang pertama kali membangun sebuah tempat belajar bagi para gadis di masanya. Wanita yang telah dicerdaskan oleh pendidikan mempunyai pemikiran yang lebih luas dan bebas, kesadaran akan potensi dan hak yang mereka miliki membuat wanita bangkit untuk berjuang mematahkan sistemsosial dan stigma tersebut (Hydrococo, 2019).

Abad 21 telah ditetapkan
sebagai masa kejayaan dan
kepemimpinan wanita (Lestari,
2018). Namun nyatanya reaksi konservatif masih sering muncul muncul melalui paham kebudayaan lokal yang justru menyokong dalam pembuatan peraturan daerah yang bersifat diskriminatif. Sejak tahun 2009, Komisi Nasional Anti Kekerasan Perempuan menemukansetidaknya 333 peraturan 
daerah yang sifatnya diskriminatif terhadap wanita (Arigi, 2018).

Kementerian Pemberdayaan Perempuan dan Perlindungan Anak menyatakanbahwa ketidaksetaraan gender dalam tenaga kerja di Indonesia masih tinggi, dibuktikan dengan jumlah Tingkat Partisipasi Angkatan Kerja (TPAK) wanita pada tahun 2018 hanya sebesar 55,44\% sedangkan pria mencapai angka $83,01 \%$ menurut data dari Badan
Pusat Statistika (Dania, 2019). Hal serupa juga dapat dilihat pada Tabel 1 yang menunjukan bahwa angka persentase tenaga kerja formal menurut jenis kelamin pada tahun 2015-2018 tidak ada peningkatan yang signifikan untuk tenaga kerja wanita (Badan Pusat Statistik, 2018).

Tabel 1. Persentasi Tenaga Kerja

Formal Menurut Jenis Kelamin

\begin{tabular}{|c|c|c|c|c|}
\hline \multirow{2}{*}{ Jenis Kelamin } & \multicolumn{4}{|c|}{ Tahun } \\
\cline { 2 - 5 } & $\mathbf{2 0 1 5}$ & $\mathbf{2 0 1 6}$ & $\mathbf{2 0 1 7}$ & $\mathbf{2 0 1 8}$ \\
\hline Pria & 44.89 & 45.05 & 45.66 & 46.29 \\
\hline Wanita & 37.78 & 38.16 & 38.63 & 38.20 \\
\hline
\end{tabular}

Sumber: Olahan Peneliti

Hal tersebut sangat disayangkan mengingat dengan meningkatkan kesetaraan gender di Indonesia dapat menambah Produk Domestik Bruto (PDB) hingga 135 miliar di tahun 2025, menurut United Nations Global Compact dan UN Woman (Anggita, 2019).

Keberanian wanita dalam mematahkan stigma dan sistem sosial yang mengekang tersebut membuka kesempatan bagi mereka untuk bisa juga berprofesi di ranah pekerjaan pria meskipun jumlah dan tugasnya masih terbatas. Salah satu contoh dari profesi tersebut adalah polisi wanita.

Menjadi seorang polwan bukanlah perkara yang mudah. Sebagai seorang wanita, polwan harus bisa menghadapi berbagai macam tantangan dan tentangan konservatif masyarakat terhadap profesinya yang dipengaruhi oleh budaya, agama dan sistem sosial. Polwan juga diwajibkan siap dalam mengemban tugas menghadapi kekerasan yang bermakna maskulin serta diharapkan memiliki sisi fenimin dalam bertindak dan mengayomi masyarakat. Selain itu, mereka juga memiliki beban domestik dalam keluarga sebagai seorang istri sekaligus ibu bagi anakanaknya (Edi, 2020).

Jenderal Polisi Tito Karnavian menyebutkan bahwa jumlah polwan saat ini masih minim, yaitu sebanyak $8,3 \%$ dari jumlah keseluruhan POLRI atau

setara dengan 36.595 orang (Makki, 2018). Walaupun jumlahnya yang masih minim, polwan harus bisa menghadapi resiko tersebut berawal dari dirinya sendiri. Polwan 
diharapkan memiliki pendirian berupa konsep diri yang kuat sehingga tidak terpengaruh dengan pandangan yang tidak membangun. Konsep diri tersebutlah yang menjadi dasar pemikiran mereka atas pernyataan eksistensi diri sebagai seorang wanita yang bebas.

Konsep diri tidak hanya sebuah persepsi yang meliputi psikologi, sosial dan fisis tentang pandangan dan perasaan diri kita sendiri, tetapi juga meliputi penilaian kita tentang diri sendiri. Setiap orang akan bertingkah laku sependapat mungkin dengan konsep dirinya sendiri. Komunikasi merupakan salah satu hal yang dapat memengaruhi konsep diri seseorang. Salah satu bentuk komunikasi yang dianggap paling efektif dalam memengaruhi seseorang adalah komunikasi interpersonal. Bagaimana seseorang memandang dirinya melalui interaksinya dan hubungannya dengan orang lain merupakan salah satu pembentukan konsep diri melalui komunikasi interpersonal.

Walaupun kajian konsep diri sangat umum digunakan dalam sebuah penelitian, subjek yang diteliti pada penelitian ini merupakan subjek yang tidak umum ditemukan dalam kajian tersebut. Hal tersebut dibuktikah setelah peneliti melakukan survey menyeluruh pada hari Jumat, 8 Oktober 2020 melalui website Open Library Universitas Telkom, dengan keyword "Konsep Diri" dari tahun 2015 hingga 2020. Hasil survei yang telah dilakukan ditampilkan pada Gambar 1.

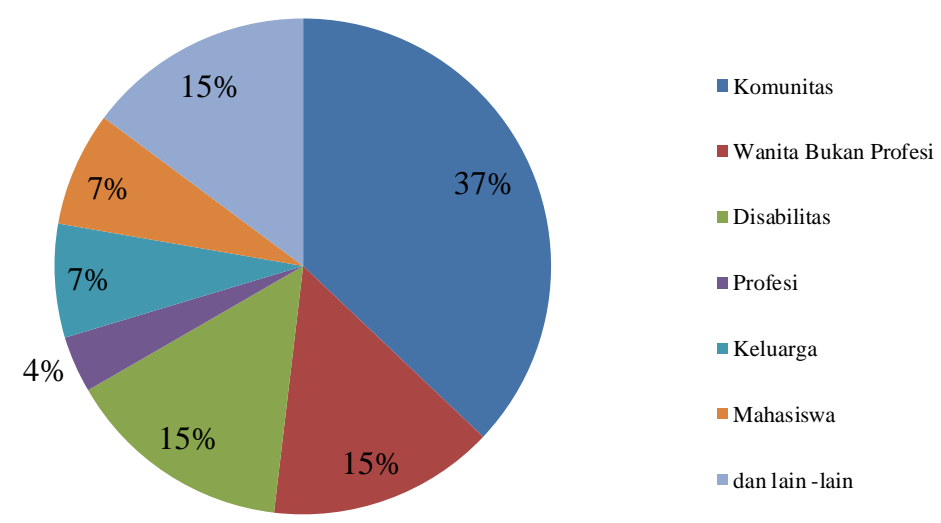

Gambar 1. Survei Open Library Telkom

Sumber: Olahan Peneliti

Hasil survei menunjukan bahwa terdapat 27 penelitian yang membahas tentang konsep diri dengan berbagai subjek yang berbeda. Jumlah penelitian konsep diri terbanyak berjumlah $37 \%$ yang membahas tentang komunitas dan 
paling sedikit berjumlah $4 \%$ membahas tentang profesi bukan polwan, yaitu TNI. Berdasarkan hasil survey tersebut dapat dinyatakan bahwa penelitian ini belum pernah dilakukan sebelumnya dan terdapat pembaharuan penelitian berupa subjek penelitian yaitu Polisi Wanita belum pernah digunakan sebelumnya pada kajian penelitian konsep diri.

Berdasarkan riset terdahulu yang sejenis dan fenomena yang telah dijelaskan diatas, maka peneliti tertarik untuk fokus meneliti tentang konsep diri dalam konteks komunikasi interpersonal polwan yang bertugas di Polres Metro Bekasi, tepatnya berlokasi di Karangasih, Jl. Ki Hajar Dewantara No.1, Simpangan, Kawasan Jababeka, Cikarang Utara, Kabupaten Bekasi, Jawa Barat (ITWASDA Polda Metro Jaya, 2020).

Polres Metro Bekasi dipilih sebagai lokasi bertugasnya subjek penelitian karena letaknya yang strategis, penghargaan dan dampak positif yang diberikan oleh Polres Metro Bekasi khususnya polisi wanita kepada masyarakat sekitar.

Polres Metro Bekasi berada di kawasan Jababeka yang terdiri atas dua kawasan yaitu kawasan industri dan perumahan. PT Jababeka Tbk sendiri merupakan pengembang kawasan industri terbuka pertama di Indonesia, yang terdaftar di Bursa Efek Jakarta dan Surabaya pada tahun 1994. Terdapat lebih dari 1.650 perusahaan multinasional dari 30 negara yang terdaftar di kawasan industry Jababeka, dengan total area industry sebesar 2.590 ha. Polres Metro Bekasi memiliki peran yang sangat penting dalam membina keamanan dan ketertiban kawasan.

Penelitian ini dibatasi pada konsep diri polisi wanita dalam konteks komunikasi interpersonal di Polres Metro Bekasi berdasarkan teori interaksi simbolik, teori komunikasi interpersonal dan teori konsep diri. Adapun tujuan dari penelitian ini adalah untuk memahami dan mengetahui detail gambaran dari konsep diri polisi wanita dalam konteks komunikasi interpersonal di Polres Metro Bekasi, melalui pengalaman dan interaksi sosial selama mereka berdinas menjadi seorang polwan, sehingga dapat bermanfaat untuk memberikan gambaran kepada caloncalon polwan selanjutnya dalam menghadapi tantangan yang akan mereka hadapi di lingkungan sosialnya.

\section{KerangkaTeori}

\subsection{Komunikasi}

Menurut West dan Turner (2017:48 ), proses sosial ketika individu menggunakan simbol untuk membentuk dan menjelaskan makna dalam lingkungan mereka disebut dengan komunikasi.

\subsection{Interaksi Simbolik}

MenurutGeorge Herbert Mead pada dasarnya setiap individu mendapatkan dorongan untuk bertindak berdasarkan pada makna yang mereka berikan kepada individu lain, benda dan peristiwa. Makna tersebut dikemas dalam bahasa yang digunakan individu tersebut baik dalam berkomunikasi dengan orang lain dan berbicara dengan diri sendiri atau pikiran mereka pribadi. Manusia bertindak 
berdasarkan pada makna simbolis yang digunakan dalam situasi tertentu. Simbol tersebutlah yang membentuk dasar Teori Interaksi Simbolis, teori berpusat pada hubungan antar simbol dan interaksi antara manusia yang menggunakan simbol tersebut (West dan Turner, 2017:72-74).

Namun makna yang di diinterpretasikan oleh individu bisa berubah dari waktu ke waktu sejalan dengan perubahan situasi dalam interaksi sosial. Kenyataan bahwa individu memiliki proses mental, yaitu bisa berkomunikasi dengan dirinya sendirilah yang menyebabkan perubahan interpretasi tersebut (Mulyana, 2018:109-110).

\subsection{Komunikasi Interpersonal}

Komunikasi interpersonal cenderung melihat pada proses keintiman terjadinya komunikasi tersebut, dengan tujuan pesan yang disampaikan akan mendapatkan efek yang langsung. Komunikasi interpersonal dimulai dengan pendekatan psikologis, yaitu dengan membangun kedekatan dan keakraban (Hanani, 2017:14-15).

\subsection{Konsep Diri}

Teori keempat adalah teori konsep diri. Menurut William D. Brooks dalam Rakhmat (2019:122-123) konsep diri aalah persepsi tentang diri kita baik itu yang bersifatfisik, sosial dan psikologi yang kita dapatkan memalui pengalaman dan berinteraksi dengan orang lain.

Charles Horton Cooley dalam Rakhmat (2019:121-122) menyatakan bahwa seorang individu bisa sekaligus menjadi subjek dan objek persepsi sekaligus dengan cara membayangkan dirinya sebagai orang lain dalam benaknya. Cooley menyebutnya sebagai gejala looking glass self atau cermin diri. Cermin diri tersebut membawa individu kedalam gambaran dan penilaian akan dirinya, hal tersebutlah yang kemudian disebut dengan konsep diri. Melalui cermin diri individu membayangkan:

a. Bagaimana dirinya tampak pada orang lain,

b. Bagaimana orang lain menilai penampilan dirinya,

c. Bagaimana perasaan kita terhadap penilaian tersebut.

Menurut Rakhmat (2019:128136) terdapat empat hal yang membuat konsep diri menjadi faktor yang sangat menentukan dalam komunikasi interpersonal, yaitu:

a. Nubuat yang dipenuhi sendiri, yaitu setiap orang memiliki kecenderungan untuk berperilaku sesuai dengan konsep dirinya.

b. Membuka Diri, yaitu dengan berkomunikasi maka pengetahuan tentang dirinya akan meningkat.

c. Percaya diri, yaitu konsepdiri yang sehat diperlukan untuk meningkatkan kepercayaan diri seseorang.

d. Selektivitas, yaitu konsep diri berpengaruh pada pesan yang diterima, cara meresapi pesan, hal-hal yang diingat dan bagaimana individu menyusun lambang-lambang sebagai arti dalam pikirannya. 


\section{Metode Penelitian}

Penelitian ini menggunakan metode penelitian kualitatif dengan paradigma interpretif. Menurut Sharan B. dan Merriam dalam Sugiyono (2020:4-5) penelitian kualitatif berfungsi untuk menemukan dan memahami fenomena utama, memahami bagaimana individu menginterpretasikan pengalamannya dan mengkonstruksi apa yang telah merekaalami. Paradigma interpretif merupakan metode untuk memahami makna sosial dengan melihat kepada fakta yang dianggap sebagai sesuatu yang unik, memiliki konteks dan essensi (Muslim, 2016:78-79).

Adapun landasan berpikir yang digunakan peneliti dalam penelitian ini adalah dengan pendekatan fenomenologi. Pendekatan fenomenologi dianggap tepat dalam penelitian ini karena peneliti berusaha untuk menggali pengalaman serta makna pengalaman bagi subjek, yaitu sebagai seorang wanita yang berprofesi sebagai polisi wanita. Paradigma serta pendekatan yang digunakan dalam penelitian ini akan lebih nyaman bagi peneliti serta subjek untuk mengungkapkan dirinya secara alami, didukung dengan pertanyaan-pertanyaan penelitian. Teknik pengumpulan data dalam pendekatan ini tidak hanya menghasilkan data yang tampak tetapi juga dapat menggali data yang tidaktampak 2008:170-171).

(Hasbiansyah,

Penelitian ini menggunakan teknik pengambilan sampel nonprobability sampling, dengan teknik sampling yang digunakan adalahpurposive sampling, yaitu teknik pengambilan sampel sumber data dengan beberapa pertimbangan atau kriteria tertentu (Sugiyono, 2020: 94-96). Purposive sampling dilakukan kepada seluruh polwan di Polres Metro Bekasi yang berjumlah 66 orang. Adapun pertimbangan atau kriteria yang digunakan adalah:

a. Merupakan anggota aktif kepolisian di Polres Metro Bekasi.

b. Memiliki waktu yang memadai untuk diminta informasi, mengingat padatnya jadwal kepolisian Polres Metro Bekasi karena kegiatan penertiban lingkungan dan kesehatan di Kabupaten Bekasi sebagai dampak dari penyebaran virus Covid-19.

c. Minimal telah berdinas sebagai polwan selama 4 tahun.

d. Setiap informan mewakili satu pangkat yang ada di Polres Metro Bekasi sehingga terdapat perbedaan pengalaman dalam berdinas.

e. Tergolong cukup asing bagi peneliti, sehingga lebih menggairahkan untuk dijadikannya narasumber.

Berdasarkan pertimbangan kriteria tersebut terpilihlah sebanyak empat orang polisi wanita. Jumlah tersebut dinilai sudah cukup untuk mendapatkan informasi yang dibutuhkan dalam penelitian karena setiap informan telah memenuhi kriteria informan yang dibutuhkan.

Penulis memberikan kode kepada setiap informan untuk mempermudah pembahasan serta menjaga kerahasiaan atribut dan identitas informan kunci. Kode setiap informan kunci dijelaskan pada Tabel 2. 
Tabel 2. Informan Kunci Penelitian

\begin{tabular}{|c|c|}
\hline Kode & Pangkat \\
\hline$(\mathrm{WU})$ & Ajun Komisaris Polisi (AKP) \\
\hline$(\mathrm{RO})$ & Brigadir PolisiKepala (Bripka) \\
\hline$(\mathrm{DE})$ & Brigadir Polisi Satu (Briptu) \\
\hline (VA) & Brigadir Polisi Dua (Bripda) \\
\hline
\end{tabular}

Sumber: Olahan Peneliti (2020)

Informan ahli dalam penelitian ini adalah seorang psikolog, yaitu Bapak Barkah Sanyoto, S.Psi, M.Psi. Adapun teknik pengumpulan data yang digunakan dalam penelitian ini, yaitu:

a. Observasi terus terang dan tersamar (over observation and cover observation), yaitu peneliti mengatakan secara terus terang kepada informan penelitian bahwa sedang melakukan penelitian, sehingga mereka tau sejak awal bahwa mereka merupakan objek penelitian, tetapi pada suatusaat juga dilakukan secara tersamar (Sugiyono, 2020:108).

b. Wawancara tidak terstruktur atau disebut juga dengan wawancara mendalam. Wawancara mendalam bersifat luwes, saat wawancara berlangsung susunan pertanyaan dan kata-kata dalam setiap pertanyaan bisa diubah untuk disesuaikan dengan kebutuhan, kondisi serta karakteristik sosial budaya informan (Mulyana, 2018:226233).

c. Dokumentasi, dokumentasi bisa berupa tulisan, gambar, atau karya. Studi dokumentasi merupakan pelengkap dari

$$
\begin{array}{llr}
\text { metode } & \text { observasi dan } \\
\text { wawancara } & \text { (Sugiyono, 2020: } \\
\text { 124-125). } & &
\end{array}
$$

Peneliti melakukan kegiatan wawancara mendalam kepada setiap informan kunci di kantorPolres Metro Bekasi. Hal tersebut mempermudah penulis dalam melakukan observasi sebelum, selama dan setelah kegiatan wawancara berlangsung. Kegiatan observasi dan wawancara mendalam dilakukan pada Rabu, 16 Desember 2020 dan Senin, 1 Februari 2021 denganwaktu yang berbeda-beda pada setiap informan. Durasi wawancara mendalam dilakukan selama \pm 30 menit sampai dengan paling lama \pm 1 jam 30 menit.

Teknik analisis data yang digunakan peneliti sebagai acuan dalam penelitian ini adalah model analisis data Miles dan Huberman dalamSugiyono (2020:132-142), yang menyatakan bahwa terdapat tempat aktivitas dalam analisis data, yaitu data collection, data reduction, data display, dan conclusion drawing/verification.

\section{Hasil Penelitian dan Pembahasan}

Hasil penelitian telah melalui tahap reduksi data, sehingga menghasilkan data yang tercantum dalam poin hasil 
observasi dan wawancara mendalam. Pembahasan dimulai dari analisis konsep diri hingga didapatkannya detail konsep diri dalam konteks komunikasi interpersonal dan makna simbolis yang dipertukarkan oleh polisi wanita.

\subsection{Hasil Penelitian}

\subsubsection{Hasil Observasi}

Informan (WU) lahir di Boyolali, dan sekarang berumur 43 tahun. Beliau sudah berkeluarga dan memiliki satu orang anak. Berdasarkan hasil observasi diketahui bahwa beliau merupakan orang yang ramah, bertanggung jawab, ekspresif dan terbuka untuk menceritakan setiap pengalamannya.

Informan (RO) lahir di Bekasi, dan sekarang berumur 37 tahun. Beliau sudah berkeluarga dan memiliki tiga orang anak. Berdasarkan hasil observasi diketahui bahwa beliau merupakan orang yang sangat ramah, mudah bersosialisasi, ceria dan terbuka untuk menceritakan setiap pengalaman dan perasaan yang beliau alami selama menjadi polwan. Informan (DE) lahir di Bekasi, dan sekarang berumur 26 tahun. Beliau sudah berkeluarga dengan satu orang anak. Berdasarkan hasil observasi diketahui bahwa beliau merupakan orang yang tegas, teratur, sopan dan terbuka untuk menceritakan pengalaman dan perasaan yang beliau rasakan selama menjadi polwan.

Informan (VA) lahir di Bogor, dan sekarang berumur 25 tahun. Beliau sudah berkeluarga dan belum mempunyaianak. Berdasarkan hasil observasi diketahui bahwa beliau sebenarnya merupakan orang yang ramah, tetapi beliau kurang bisa menyatakan pendapatnya dengan ungkapan yang tepat dan lebih berhati- hati kepada orang yang baru beliau kenal.

\subsection{Hasil Wawancara Mendalam}

a. Motivasi bekerja sebagai polwan Informan (WU) tertantang untuk ikut berbuat kebaikan dalama ajaranagamanya, yaitu Amar marufnahimunkar. Informan (RO) dari dulu sudah memiliki niat untuk mengabdikan dirinya menjadipolwan. Informan (DE) sedari SMA memiliki minat pada kegiatan-kegiatan yang nota bene mirip dengan pekerjaan yang diinginkan. Informan (VA) merasa memiliki tanggung jawab sebagai anak pertama untuk mengikuti jejak ayahnya.

b. Tanggapan terhadap fenomena kepolisian sebelum menjadi polwan

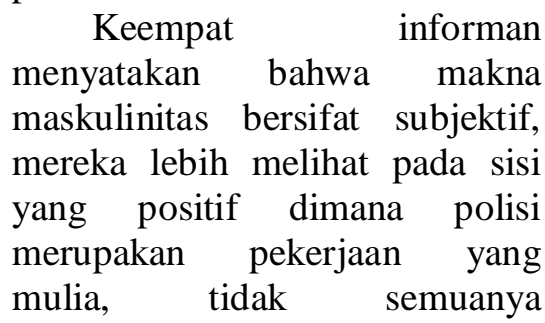
menggunakan kekerasan, gagah, sebagai sosok wanita berseragam yang dapat membanggakan orang tua dan pekerjaan yang dapat memberikan manfaat bagi banyak orang.

c. Tanggapan orang-orang terdekat memaknai fenomena di kepolisian

Keluarga setiap informan menyikapi hal tersebut dengan pikiran yang lebih terbuka. Perbedaan professi adalah hal yang biasa, tidak dapat diukur 
dengan gender dan hal tersebut adalah pilihan bagi setiap orang. Mereka merasa simpati dengan polisi yang menghadapi kerusuhan, tetapi menyadari bahwa itu merupakan bagian dari resiko pekerjaan dan di professi lain pun memiliki resiko pekerjaannya masing-masing.

Namun masih ada informan yang mendapatkan tanggapan negatif terhadap polisi berupa isu-isu pendaftaran polisi yang belum tentu kebenarannya. Beberapa di antaranya yaitu untuk bekerja menjadi polisi memerlukan koneksi orang dalam dan menyiapkan uang sebanyak 500juta.

d. Perbedaan pandangan setelah bekerja menjadi polwan

Informan menyadari bahwa menjadi seorang polisi tidak hanya bergerak di bidang penegakan hukum saja, tetapi polisi juga bisa terjun di bidang lain seperti bidang kebersihan, forensik dan edukasi masyakarat. Setelah menjadi polisi informan juga merasa memiliki keberanian untuk bertindak dan lebih peka terhadap lingkungan baik ketika berdinas maupun sehari-hari.

e. Pendapat tentang bentuk dan tingkat kepuasan terhadap tubuh fisik

Informan bersyukur dan menerima bentuk tubuh fisik mereka saat ini. Menjadi polisi merupakan pekerjaan yang menuntut informan untuk bergerak cepat, sehingga aturan tinggi dan badan yang ideal merupakan sebuah keharusan. Saat ini yang terpenting adalah sehat dan sehat itu ada ukurannya, beberapa diantaranya adalah pola makan, istirahat, control guladarah, kolesterol, berat badan dan tinggi badan yang ideal. Menjaga tubuh merupakan bagian dari mencintai diri sendiri.

f. Pendapat tentang watak atau karakter

Informan merupakan orang yang terbuka, suka bersosialisasi dengan banyak orang dan cenderung menyesuaikan sikap dan prilakunya sesuai dengan situasi, kondisi dan kebutuhannya. Contohnya ketika tidak sedang berdinas mereka akan bersikap lebih santai, tetapi ketika sedang berdinas dan memakai baju seragam akan bersikap lebih berwibawa dan menyesuaikan karakter atau sifat masyarakat yang mereka hadapi.

g. Perasaan bekerja sebagai polwan Informan merasa sangat senang bekerja menjadi polwan. Pekerjaannnya membuat informan lebih dekat dengan rekan-rekannya di kantor yang sudah mereka anggap seperti keluarga sendiri. Namun konsekuensi waktu bekerja membuat mereka lebih banyak menghabiskan waktunya di kantor. Informan juga bersyukur memilih untuk bekerja sebagai polwan karena merasa pekerjaannya ini mendatangkan lebih banyak manfaat dan dampak positif bagibanyak orang.

h. Hal-hal yang membuat sedih dan cemas

Keselamatan diri dan rekanrekan ketikaberdinas, khususnya ketika menghadapi kerusuhan 
massa cukup membuat informan cemas. Tetapi hal yang paling membuat informan cemas dan sedih adalah kenyataan bahwa mereka harus bersiap di situasi yang tidak dapat diprediksi, sedangkan di rumah mereka memiliki keluarga dan tanggung jawab sebagai ibu bagi anakanaknya.

i. Pendapat tentang penilaian orang lain, kesesuaian penilaian dan perasaan terhadap penilaian tersebut

Informan menyatakan bahwa penilaian yang mereka terima ada yang sesuai dan ada yang tidak.

(-) Masih ada teman-teman dan masyarakat yang memberikan penilaian negatif kepada informan tanpa mengetahui motivasi baik dibalik tindakannya. Mereka cenderung memukul rata penilaian negatif mereka terhadap polisi dan sering menyepelekan tugas polisi khususnya dalam hal keselamatan. Bagi informan hanya orang jahat yang membenci polisi. Sebagai polisi informan hanya berusaha untuk menjalankan tugasnya dengan baik,

tetapibalasandarimasyarakat yang tidaksesuaitersebutmembuatmere kasedih.

(+) Tidak jarang juga informan mendapatkan apresiasi dari masyarakat yang terbantu dengan kehadirannya, hal itu membuat informan senang dan sedikit ada rasa kepuasan di hatinya.

j. Cara menyikapi penilaian tersebut
(-) Informan tidak membenci maupun menjauhi mereka, tetap berusaha bersikap baik dan mempertahankan ide atau gagasan yang mereka anggap baik dan bermanfaat bagi banyak orang. Informan juga tidak terlalu cemas dengan penilaian tersebut.

(+) Informan senang dan berterima kasih atas apresiasi yang masyarakat berikan, tetapi hal tersebut tidak membuatnya berpuas diri dan besar kepala, karena bagi informan melakukan hal yang benar adalah keharusan.

k. Pentingnya berkomunikasi

Komunikasi merupakan hal yang sangat penting untuk mendukung informan dalam bekerja dan berkegiatan seharihari. Ketika membicarakan tugas atau pengambilan keputusan mereka melakukan komunikasi organisasi yang berhierarki. Ketika sedang berdinas yang menghadapi masyarakat informan menggunakan

komunikasi untuk melakukan pendekatan personal kepada kelompok masyarakat tertentu untuk memposisikan dirinya sebagai teman atau keluarga yang akan membantu menyelesaikan masalah yang mereka hadapi. Saling menjalin hubungan yang baik melalui komunikasi antara rekan kerja juga sangat diperlukan, karena informan bekerja sebaga isu atu kesatuan bukan hanya pekerjaan pribadi.

1. Pengalaman yang membuat informan lebih terbuka dengan fenomena baru 
Setiap informan memiliki
pengalaman $\begin{array}{r}\text { berkesan } \\ \text { berbeda, di mang }\end{array}$
pengalaman setiap
mereka untuk semakin terbuka
dan bersemangat untuk mendapatkan pengalaman baru. Pengalaman tersebut mulai dari kegiatan berdinas yang ringan seperti mendampingi calon anggota polisi, dinas pertama sebagai polisi lalu lintas dan menjadi seorang negosiator, hingga kegiatan berdinas besar di unit identifikasi dalam memecahkan kasus-kasus besar seperti kasus pembunuhan dan pemerkosaan. Bagi informan yang saat ini bekerja sebagai staff internal di kantor selalu memiliki kerinduan untuk bekerja di lapangan, bertemu dengan masyarakat yang unik dan bekerjasama dengan rekanrekannya sebagai sebuah tim.

m. Karakter Polwan

Seorang polwan harus pintar menyesuaikan diri baik perilaku, karakter dan sifat di manapun mereka ditempatkan untuk berdinas. Namun dimata organisasi polwan harus selalu siap, kuat dan tidak mudah mengeluh. Informan mengistilahkan karakter polwan itu sebagai tokoh wonder woman.

n. Harapan kepada wanita yang masih memperjuangkan hakhaknya dalam bekerja

Bagi informan, wanita harus bisa mandiri khususnya mandiri secara finansial, tidak bergantung kepada orang lain maupun pasangan, dapat memberikan manfaat bagi orang lain dan berdaya dalam menghadapi tantangan yang tidak terduga dalam hidup. Bekerja adalah salah satu caranya, dengan bekerja kita dapat memperjuangkan hak-hak kita untuk tidak direndahkan, tetap semangat, jangan putus asa dan buat kita yang sudah berharga ini menjadi lebih berharga.

\subsection{Pembahasan}

4.3.1 Pembentukan Konsep Diri Polwan

Walaupun stigma negatif
tentang polisi masih terus bermunculan, saat ini masih ada wanita-wanita yang memiliki kekuatan dan keyakinan dengan pilihannya untuk bekerja sebagai seorang polisi wanita, beberapa diantaranya adalah informan (WU), (RO), (DE) dan (VA).

Pembentukan konsep diri informan berawal dari asumsi teori interaksi simbolik yang menjelaskan bahwa individu bertindak berdasarkan makna.

Sebelum menjadi seorang polwan, keempat informan mendapatkan banyak dukungan yang positif dari keluarganya untuk bekerja sebagai polisi. Meskipun dari lingkungan pertemanan masih ada yang memiliki stigma negative tentang profesi polisi, tetapi berkat peran orangtua dan keluarga yang maksimal, informan menjadi cenderung mengolah dan menginterpretasikan makna tersebut ke sudut pandang yang lebih postif. Hal tersebutlah yang mendorong informan untuk yakin mendaftarkan dirinya sebagai polwan.

Sejalan dengan pernyataan dari informan ahli penelitian yaitu Bapak Barkah Sanyoto, S.Psi, M.Psi, 
dimana faktor terbesar yang memengaruhi konsep diri seseorang adalah keluarga. Pada usia golden age yaitu $0-5$ tahun asupan positif atau negative dari keluarga sangat memengaruhi perkembangan individu di tahap selanjutnya.

Berdasarkan hasil temuan wawancara, keluarga inti khususnya orang tua dari keempat informan memiliki peran yang dominan dalam proses pertumbuhan dan perkembangan yang positif bagi informan hingga saat ini. Dukungan maksimal yang diterima oleh informan dari keluarga tersebutlah yang membuat informan memiliki kepercayaan diri dengan pilihannya untuk mendaftarkan diri sebagai polwan walaupun ada yang pernah beberapa kali gagal.

Konsep tersebut kemudian berkembang melalui significant others dalam hal ini adalah keluarga, kelompok rujukanya itu instansi POLRI dan yang ketiga adalah pengalaman, di mana ditemukan perbedaan pada informan (VA) yang memilikipengalamanberdinas paling sedikit.

\subsubsection{Konsep Diri Polwan}

Konsep diri polisi wanita dinilai berdasarkan cermin diri yang terdiri dari tiga hal, yaitu:

a. Penilaian Diri

Informan merasa bersyukur dan menjag atubuh ideal sebagai bentuk self love. Terbuka, suka bersosialisasi dan dapat menyesuaikan watak/ karakter sesuai dengan situasi, kondisi dan kebutuhan. Senang bekerja sebagai polwan. Konsekuensi waktu dan kondisi anak serta keluarga di rumah sering membuat sedih \& cemas.

b. Penilaian Orang Lain

(+) Apresiasi dan ucapan terima kasih atas bantuannya.

(-) Memberikan penilaian negatif tanpa tahu motivasi/ alasan informan melakukan suatu hal dan masyarakat yang cenderung memukul rata penilaian negatif kepada polisi.

c. Perasaan terhadapPenilaian:

$(+)$ tidakterlaluberpuasdiri dan tidakbesarkepala.

(-) Tidak cemas, tidak membenci atau menjauhi orang tersebut dan tetap melakukan yang terbaik.

Cermin diri tersebut dapat membawa individu ke dalam gambaran dan penilaian akan dirinya, yaitu konsep diri. Berdasarkan temuan penelitian dan cermin diri informan di atas, maka konsep diri keempat informan mengarah pada konsep diri positif yang ditandai dengan 5 hal, yaitu:

a. Memiliki keyakin an akan kemampuan dirinya untuk bekerja sebagai polisi ditengahtengah masyarakat yang masih memiliki pandangan negative terhadap dunia kepolisian.

b. Merasa setara dengan orang lain dengan tidak merasa besar kepala dengan jabatan polisi yang dimilikinya, dapat menerima pujian tanpa rasa malu dan tidak berpuas diri.

c. Informan dapat menerima pujian atau apresiasi positif dengan rasa senang dan memiliki sedikit kepuasan di hati karena bisa melakukan hal yang bermanfaa tuntuk banyak orang. Tetapi hal 
tersebut tidak menjadikan mereka terlalu berpuas diri dan besar kepala, karena bagi mereka melakukan kebenaran adalah sebuah keharusan.

d. Memahami bahwa setiap orang memiliki perasaan, keinginan dan prilaku yang berbeda dan menganggap bahwa mereka yang kontra dengan keputusannya hanya belum mengetahui alasan atau motivasinya melakukan hal tersebut.

e. Memiliki kemampuan untuk memperbaiki diri menjadi lebih baik karena hal tersebut merupakan bagian dari mencintai diri sendiri.

Menurut informan ahli penelitian setiap orang yang memiliki konsep diri positif pasti bisa membangun hubungan yang baik dengan orang baru maupun orang sekitarnya, dan orang yang memiliki konsep diri negative bisa membangun komunikasi dan hubungan dengan lingkungan yang baik jika mereka mau belajar untuk membuka dirinya, memiliki keinginan untuk memperbaiki dan meningkatkan kualitas dirinya untuk menjadi lebih positif.

Pengalaman termasuk salah satu cara untuk meningkatkan kemampuan berkomunikasi dan konsep diri yang positif. Pengalaman merupakan salah satu media pembelajaran seseorang untuk menyesuaikan diri dan mengubahkonsep dirinya untukmenjadi orang yang lebih mudah beradaptasi dengan lingkungan sekitarnya. Konsep diri memengaruhi komunikasi interpersonalseseorang.

\subsubsection{Konsep Diri dalam Komunikasi Interpersonal Polwan}

Konsep diri positif yang dimiliki oleh keempat informan tersebut menjadi faktor yang sangat menentukan dalam komunikasi interpersonal informan yang dibuktikan dengan empat hal, yaitu:

a. Informan bertingkah laku sesuai dengan konsep dirinya yang positif.

b. Informan dengan kemampuan berbahasa (interpersonal) yang lebih baik cenderung terlihat lebih terbuka karena bisa menyampaikan perasaan dan pengalamannya dengan jelas, sedangkan yang kurang memiliki kemampuan berbahasa yang baik menjawab dengan singkat sehingga terkesan kurang terbuka. Namun informan tersebut mau belajar dari pengalamannya untuk menjadi lebih baik.

c. Setiap informan percaya diri dengan kemampuan dirinya serta mau membuka diri untuk belajar dan mengasah kemampuan interpersonalnya agar menjadi lebih baik.

d. Informan selektif dalam menyaring pesan \& menanggapi pesan yang diterima. Informan cenderung mengingat pengalamannya selama bekerja dan keluarga serta anaknya jika dihadapkan pada kondisi yang kurang baik. Informan selalu mengolah setiap pesan sebelum memberikan label tertentu.

Jika dilihat dari sisi pengalaman dalam temuan penelitian ini didapatkan bahwa informan 
(WU), (RO) dan (DE) telah memiliki lebih banyak pengalaman berdinas dalam menghadapi masyarakat, sehingga memiliki kemampuan komunikasi interpersonal yang lebih baik. Mereka dinilai bisa lebih baik dalam menyampaikan pendapat, pengalaman maupun perasaan yang dimiliki dengan kemampuan komunikasi interpersonal yang baik.

Informan (VA) merupakan anggota polwan dengan pangkat yang paling kecil di antara informan yang lain, pengalaman berdinas beliau pun masih sangat sedikit yaitu sebagai negosiator di Polda Metro Jaya dan pindah ke Polres Metro Bekasi sebagai staff administrasi, sehingga beliau belum banyak memiliki pengalaman berinteraksi dengan masyarakat yang menyebabkan beliau kurang bisa menyampaikan pengalaman dan perasaannya dengan ungkapan yang tepat sehingga jawab-jawabannya cenderung singkat.

Walaupun begitu beliau tetap memiliki kepercayaan diri untuk tetap tampil dan hadir, mengambil peluang pembelajaran dan pengalaman untuk mengasah kemampuan komunikasi interpersonalnya serta menghadapi tuntutan pekerjaan dan tanggungjawabnya sebagai seorang informan dan polwan.

Individu dengan konsep diri positif akan memilih untuk menghadapi masalah tersebut dan bagaimana pun hasilnya akan diterima sebagai pembelajaran dan mengevaluasi diri untuk menjadi lebih baik lagi dari sebelumnya. Tetapi jika individu memiliki konsep diri yang negative maka dia akan menghindar dari masalah tersebut sehingga menyebabkan tumbuhnya masalah baru yang tidak akan pernah terselesaikan. Akhirnya dia tidak akan mendapatkan pengalamanpengalaman serta pembelajaran yang dapat membuat dirinya lebih percayadiri dan membuat konsep dirinya menjadi lebih positif. Hal tersebutlah yang membuktikan bahwa informan (VA) juga memiliki konsep diri yang postif.

\subsubsection{Makna Simbolis yang dipertukarkan Oleh Polwan}

Berdasarkan hasil analisis konsep diri positif dalam komunikasi interpersonal polwan diatas, maka didapatkanlah makna simbolis yang dipertukarkan oleh polisi wanita melalui bahasa yang dikemas dengan pemaparan pengalaman dan pengetahuan murni hasil pemikiran yang mereka miliki, yaitu sebagai berikut:

a. Amar maruf nahi munkar

Merupakan salah satu hadist dalam agama Islam yang bermakna tentang kebanggaan seorang muslim ketika dapat melakukan sesuatu sebagai upaya tolong-menolong dalam berbuat kebaikan dan saling mengingatkan dalam keburukan.

Dijelaskan bahwa selemah lemahnya iman adalah orang yang hanya mampu menolak dalam hati ketika terjadi keburukan. Namun polisi memiliki jabatan dan kedudukan untuk melakukan sesuatu ketika terjadi keburukan, dan itu adalah kebanggaannya.

b. Wanita berseragam membanggakan

Seragam dalam profesi ini merupakan salah satu bentuk 
kebanggan bagi anggotanya, dibuktikan ketika diprofesilain, setelah bekerja mereka cenderung mengganti seragamnya menggunakan pakaian sehari-hari setelah selesai bekerja, tetapi bagi polisi dengan memakai seragamnya saat pulang kerumah untuk bertemu anak dan keluarganya merupakan sebuah kebanggaan yang berbeda.

$\begin{array}{lr}\text { Seragam } & \text { dapat } \\ \text { mencerminkan karakter } & \text { dan } \\ \text { wibawa seorang polisi yang }\end{array}$ dapat dibanggakan tanpa harus berbicara. Memperlihatkan posisi dia pada masyarakat di kondisi tertentu. Misalnya saat hadir pada sebuah pertemuan personal (pengambilan rapot anak) sambil memakai seragam.

c. Resiko pekerjaan

Memahami bahwa semua pekerjaan adalah sama dan memiliki resikonya masingmasing. Menghadapi kerusuhan dan situasi mencekam yang sulit diprediksi merupakan resiko bekerja sebagai polisi, begitu juga dengan profesi lain yang memiliki resiko pekerjaannya masing-masing.

d. Keberanian dalam bertindak

Seorang polisi dilatih untuk lebih peka terhadap lingkungan sekitar, sehingga keberanian dalam bertindak diperlukan untuk mengayomi dan melindungi masyarakat baik saat berdinas maupun di kehidupansehari-hari.

e. Sehat ada ukurannya

Menjadi polisi menuntut mereka untuk dapat bergerak cepat, sehingga memiliki badan yang sehat merupakan sebuah keharusan. Beberapa ukuran sehat tersebut ditentukan berdasarkan berat badan dan tinggi badan yang ideal, pola makan yang sehat, kontrol kolesterol dan gula darah. Ukuran kesehatan tersebut harus dipenuhi karena itu juga merupakan bagian dari mencintai diri sendiri.

f. Penyesuaian Karakter

Seorang polwan diharuskan dapat menyesuaikan karakternya dengan situasi, kondisi dan masyarakat yang dihadapinya. Ketika sedang tidak memakai seragam dan bersama temantemannya mereka akan cenderung lebih santai, tetapi ketika sudah memakai seragam mereka akan bersikap lebih berwibawa.

Ketika memakai seragam mereka memikul tanggung jawab yang lebih besar sebagai seorang polwan seutuhnya, selain itu dengan berseragam membawa kehormatan instansi kepolisian. Sehingga sikap, tutur kata dan karakter yang mereka miliki harus berwibawa mencerminkan seorang polisi.

g. Pekerjaan bermanfaat

Selain bekerja di bidang hukum, polisi juga bertugas di bidang lain seperti di bidang forensik, kebersihan, pemberdayaan lingkungan yang tidak lain bertujuan untuk mengedukasi dan mengayomi masyarakat. Polisi harus bisa terjun di manapun masyarakat berada serta memberikan manfaat yang dapat berdampak positif bagi mereka. Polisi merupakan pekerjaan yang dapat membawa 
banyak manfaat bagi banyak orang.

h. Tanggungjawabsebagaiibu

Pada dasarnya polisi dilatih untuk melindungi masyarakat dan orang-orang sekitarnya, sehingga pelatihan tersebut menyebabkan mereka semakin peka atau simpatik dengan keselamatan orang lain. Ketika menghadapi kerusuhan tingkat kecemasan terhadap keselamatan mereka bukanlah yang terbesar. Mereka lebih cemas terhadap kondisi keluarga dan khususnya bagi seorangpolwan yang memiliki anak sesuai dengan naluri keibuannya, mereka akan sangat cemas dengan kondisi anak mereka dirumah bila hal buruk menimp amereka.

i. Orang jahat membenci polisi

Polisi bertugas untuk mengedukasi dan mengarahkan masyarakat untuk lebih patuh kepada peraturan atau undangundang yang berlaku, khususnya dalam hal keselamatan. Masih banyak masyarakat yang menyepelekan tugas polisi tersebut dan justru memberikan cap negative atau menyudutkan posisi polisi yang sebenarnya bermaksud baik. Bahkan tidak jarang masyarakat memukul rata penilaian negative mereka kepada semua polisi.

Walaupun berhadapan dengan masyarakat yang seperti itu polisi harus bisa tetap dengan sabar menjalankan tugasnya untuk mengarahkan mereka menjadi masyarakat bernegara yang lebih baik lagi.

j. Berbuat baik adalah kewajiban
Bagi seorang polwan merasa berbuat baik bukan hal yang istimewa karena menurut polisi berbuat baik adalah kewajiban semua orang.

k. Bekerja sebagai suatu kesatuan

Kemampuan berkomunikasi, koordinasi dan memupuk kedekatan interpersonal antar anggota maupun masyarakat dibutuhkan bagi seorang polwan. Sebagai seorang polisi semua alur pengambilan keputusan, komunikasi dan koordinasi berada dalam jalur yang saling berhubungan satu sama lain, mereka bekerja sebagai sebuah kesatuan dan bukan hanya sekedar keberhasilan pekerjaan perorangan tetapi keseluruhan instansi.

1. Kerinduan bekerja di lapangan

Setiap polisi memiliki kesempatan untuk bekerja sebagai staff di kantor dan bekerja di lapangan yang dapat berhubungan langsung dengan masyarakat. Bagimereka yang bekerjamenjadi staff, selalu memiliki kerinduan tersendiri untuk kembali terjun ke masyarakat. Karakter masyarakat yang bervariasi, bekerja bersama rekan-rekan sebagai sebuah tim dan dihadapkan pada kondisi yang sulit ditebak membuat mereka merasa bersemangat dan tidak sabar untuk mendapatkan pengalaman-pengalaman bermakna lainnya.

$\mathrm{m}$. Karakter wonder woman

Seluruh personil kepolisian dilatih untuk selalu siap siaga menghadapi tugas dan massalah setiap harinya, baik yang dapat 
diprediksi maupun tidak. Polisi tidak boleh lengah apalagi menghindari tugas dan kewajibannya di masyarakat dan di hadapan instansi kepolisian itu sendiri. Karakter seorang wonder woman yang kuat, tidak mudah menyerah dan dapat menempatkan dirinya dengan baik dimanapun dan kapanpun, merupakan karakter yang harus dimiliki oleh setiap polwan.

n. Wanita mandiri

Menjadi seorang polwan merupakan salah satu professi untuk menjadi wanita yang mandiri baik secara pribadi dan finansial, berdaya dalam menghadapi tantangan yang tidak terduga dalam hidup dan membuat diri kita sebagai seorang wanita yang sudah berharga menjadi semakin berharga, karena dengan bekerja kita dapat mengasah potensi dan kemampuan yang diri.

\section{Kesimpulan}

Konsep diri yang dimiliki oleh polisi wanita di Polres Metro Bekasi adalah konsep diri positif, dimana keluarga terlihat memiliki peran yang paling dominan dalam membentuk konsep diri positif setiap informan, konsep diri tersebut kemudian berkembang melalui pengalaman dan interaksisosial. Konsep diri positif dibutuhkan dalam mengasah kemampuan komunikasi interpersonal informan baik saat berdinas maupun dalam kehidupan sehari-hari. Pada komunikasi interpersonal, konsep diri positif mengambil peran penting salah satunya dalam kepercayaan diri informan untuk mengambil peluang pengalaman mengasah kemampuan komunikasi interpersonalnya agar lebih baik. Berdasarkan hasil penelitian didapatkan juga empat belas makna simbolis yang dipertukarkan oleh polwan melalui pemaparan pengalaman dan pengetahuan murni hasil pemikiran mereka, dimana simbol- simbol tersebut diharapkan dapat menjadi acuan bagi calon-calon polwan selanjutnya dalam menghadapi tantangan pekerjaannya yang akan datang.

\section{Daftar Pustaka}

Artikel Jurnal:

Hasbiansyah, O. (2008). Pendekatan Fenomenologi: Pengantar Praktik Penelitian dalam Ilmu Sosial dan Komunikasi. Mediator, 163-180.

Muslim. (2016). Varian-Varian Paradigma, Pendekatan, Metode, dan Jenis Penelitian dalam Ilmu Komunikasi. Wahana, 77-85.

Buku:

Hanani, S. (2017). Komunikasi Antarpribadi:Teori dan Praktik. Yogyakarta: Ar-Ruzz Media

Mulyana, D. (2018). Metodelogi Penelitian Kualitatif (Edisi Revisi). Bandung: PT Remaja Rosdakarya Offset.

Rakhmat, J. (2019). Psikologi Komunikasi (Edisi Revisi). Bandung: Simbiosa Rekatama Media. 
Sugiyono. (2020). Metode Penelitian Kualitatif (Edisi ke-3). Bandung: Alfabeta.

West, R., \& Turner, L. H. (2017). Pengantar Teori Komunikasi: Analisis dan Aplikasi. Jakarta: Salemba Humanika

Internet:

Anggita, K. (2019). Ketidaksetaraan Gender di Indonesia Masih Tergolong Tinggi. Retrieved February 15, 2020, from medcom.id website: https://www.medcom.id/rona/k eluarga/9K5r2zxNketidaksetaraan-gender-diindonesia-masih-tergolongtinggi

Arigi, F. (2018). Komnas Perempuan: Ratusan Perda Diskriminatif Terhadap Perempuan. Retrieved February 15, 2020, from nasional.tempo.co website: https://nasional.tempo.co/read/ 1147997/komnas-perempuanratusan-perda-diskriminatifterhadapperempuan/full\&view $=$ ok

Badan Pusat Statistik. (2018). Persentase Tenaga Kerja Formal Menurut Jenis Kelamin, 2015-2018. Retrieved February 20, 2020, dari bps.go.id:

https://www.bps.go.id/dynamic table/2018/05/16/1313/

persentase-tenaga-kerjaformal-menurut-jenis-kelamin2015---2018.html

Dania, R. (2019). KemenPPPA Sebut Kesenjangan Gender dalam Pekerjaan Masih Tinggi. Retrieved February 15, 2020, from tirto.id webiste: https://tirto.id/kemenpppasebut-kesenjangan-genderdalam-pekerjaan-masih-tinggiefxa

Hydrococo. (2019). Awal Mula Berkembangnya Emansipasi Wanita. Retrieved February 20, 2020, from hydrococo.com website:

http://www.hydrococo.com/aw al-mula-berkembangnyaemansipasi-wanita/

ITWASDA Polda Metro Jaya. (2020). Oktober 12). Polres Metro Kabupaten Bekasi. Retrieved January 15, 2021, from itwasda.metro.polri.go.id website:

https://itwasda.metro.polri.go.i $\mathrm{d} /$ region/detail/polres-metrokabupaten-bekasi

Lestari, L. A. (2018). Emansipasi Wanita Abad 21. Retrieved February 15, 2020, from potretbengkulu.com website: https://potretbengkulu.com/201 8/04/22/emansipasi-wanitaabad-21/

Makki, S. (2018). Tito Belum Puas dengan Jumlah Polwan dalam Tubuh Polri. Retrieved February 15, 2020 from cnnindonesia.com website: https://www.cnnindonesia.com /nasional/20181227142912-20356761/tito-belum-puasdengan-jumlah-polwan-dalamtubuh-polri 